\title{
Autotransplantation of Cryopreserved/Thawed Ovarian Tissue: Overview of Methods and Challenges
}

\author{
Dondurulmuş/Çözülmüş Over Dokusunun Ototransplantasyonu: \\ Yöntem ve Sorunlara Genel Bakış \\ Hulya Ayik Aydin ${ }^{1}$, A. Yasemin Goksu Erol ${ }^{2,3}$, Armagan Aydin ${ }^{4}$ \\ ${ }^{1}$ Department of Obstetrics and Gynecology, Gynecological Oncology Department, Faculty of Medicine, \\ Akdeniz University, Antalya, Turkey \\ ${ }^{2}$ In Vitro Fertilization Center, Faculty of Medicine, Akdeniz University, Antalya, Turkey \\ ${ }^{3}$ Department of Histology and Embryology, Faculty of Medicine, Akdeniz University, Antalya, Turkey \\ ${ }^{3}$ Department of Medical Oncology, Antalya Training and Research Hospital, Antalya, Turkey \\ Yazışma Adresi / Correspondence: \\ Hülya Ayık Aydın
}

Department of Obstetrics and Gynecology, Division of Gynecologic Oncological Surgery, Akdeniz University School of Medicine, 07059, Konyaalti, Antalya, Turkey T: +90507 7080245 E-mail: hulya_ayik@hotmail.com

Geliş Tarihi / Received : 02.01.2019 Kabul Tarihi / Accepted : 26.02.2019

\begin{abstract}
Objective In recent years, an increasing number of women diagnosed with malignant or non-malignant diseases have been subjected to cytotoxic chemoradiotherapy. Women who face the possibility of premature ovarian failure caused by cytotoxic therapy may retain their fertility potential via ovarian tissue cryopreservation. Despite its advantages, this fertility preservation method for women at risk of losing reproductive function is considered experimental due to 1) a possible decrease in the ovarian follicular pool as a result of cryopreservation and thawing procedures (although this has been minimised by improved methods), or by ischemic damage occurring in the graft during ovarian transplantation; and 2) the risk of minimal residual disease for cancer patients which can be defined as reintroducing pre-existing cancer cells in ovarian tissue before cryopreservation. Although the indications for ovarian cryopreservation now extend beyond cancer, cancer survivors remain as the patient population who most commonly need this procedure. For these patients, the risk of minimal residual disease is an important challenge for the application of this method. Even though the risk of reimplanting pre-existing cancer cells through ovarian transplantation is minimal or non-existent for most types of cancer, this risk must be ascertained according to cancer type and disease stage. Moreover, the efficacy of ovarian tissue transplantation is determined by the degree of success in minimising follicular loss. For this purpose, many experiments aim to reduce ischemic damage in transplanted ovarian grafts, and to determine the best methods/protocols for human ovarian cryopreservation, comparing 'slow freezing' and 'vitrification'. ( Sakarya Med J 2019, 9(1):1-10)

Keywords Human ovary; cryopreservation; transplantation; fertility preservation; minimal residual disease
\end{abstract}

$\ddot{O} z$

Son yıllarda malign veya malign olmayan hastalık teșhisi alan artan sayıda kadın hasta sitotoksik kemoradyoterapiye maruz kalmıștrr. Sitotoksik tedavinin neden olduğu erken ovaryan yetmezlik olastlĭğna maruz kalan kadınlar, ovaryum dokusunun dondurularak korunmast yoluyla doğurganlı potansiyellerini koruyabilirler. Avantajlarına rağmen, üreme fonksiyonunu kaybetme riski tașlyan kadınlarda bu fertilite koruma yöntemi henüz deneysel kabul edilmektedir. Bunun en önemli iki nedeni; 1) Ovaryan foliküler havuzda bir azalma durumu: Geliștirilmiş yöntemler ile en aza indirilmiş olmasına rağmen kriyoprezervasyon ve çözülme prosedürlerinin bir sonucu olarak ve ovaryan transplantasyon esnastnda meydana gelen iskemik hasar nedeni ile görülmektedir. 2) Minimal rezidüel hastallk riski: Kanser hastaları için ovaryum dokusunda dondurma öncesi var olan kanser hücrelerinin ovaryum transplantasyonu yoluyla tekrar hastaya verilme riski olarak tanımlanabilir. Her ne kadar ovaryan kriyoprezervasyon endikasyonları kanserin ötesine geçse de, kanserden kurtulanlar bu ișleme en çok ihtiyaç duyan hasta popülasyonudur. Bu hastalar için minimal rezidüel hastalık riski, bu yöntemin uygulanmasında önemli bir sıkıntıdr. Önceden var olan kanser hücrelerinin yeniden yerleștirilme riski çoğu kanser tipinde olmasa ya da minimal olsa da, bu risk kanser tipine ve hastalk evresine göre tespit edilmelidir. Ayrıca, ovaryan doku transplantasyonunun etkinliği, ovaryan foliküler kaybın azaltılmasındaki başarı oranı ile ortaya konabilecektir. Bu amaçla çok sayıda deney, transplante over graftında iskemik hasarı azaltmaya ve insan over dokusunun kriyoprezervasyonunda 'slow freezing've 'vitrifikasyon' yöntemlerinin karşslaştırlarak en iyi yöntem/protokolü belirlemeye çalş̧maktadır. ( Sakarya Tip Dergisi 2019, 9(1):1-10). 


\section{Introduction}

Surgical, medical, and technological developments in cancer therapies have led to improvements in quality of life and survival rates; however, preservation and maintenance of fertility are also of great importance. Women of reproductive age are at risk for a wide variety of cancer types, with breast cancer being the most frequent. Furthermore, 4,000 girls are exposed to chemotherapy (CT) and/or radiotherapy (RT) every year, which may potentially cause sterility. Over the last few decades, cancer therapy during childhood and adolescence has greatly improved survival rates. Whereas the 5-year survival rate has increased from $56 \%$ to $64 \%$ among adult women, it has increased from $56 \%$ to $75 \%$ among children. ${ }^{1-3}$

Factors playing a role in the preservation of fertility are related to age at the time of diagnosis, type, location, and severity of cancer, and also treatment protocols received by the patient. Cancer treatment today consists mainly of conservative surgery, CT, and RT. Using these current treatment modalities in some cancer types, such as breast cancer, cure rates have exceeded 90\%. However, there are very few effective clinical methods to preserve female fertility following aggressive CT and RT protocols. The adverse effects of chemotherapeutic agents or radiation on ovarian function are generally progressive, and mostly irreversible, leading to permanent amenorrhea and infertility. ${ }^{4}$

Importantly, these group of patients at risk of losing reproductive function may retain their fertility potential via ovarian tissue cryopreservation. Despite its advantages, this fertility preservation method for women is considered experimental due to 1 ) a possible decrease in the ovarian follicular pool as a result of cryopreservation and thawing procedures (although this has been minimised by improved methods), or by ischemic damage occurring in the graft during ovarian transplantation; and 2) the risk of minimal residual disease for cancer patients which can be defined as reintroducing pre-existing cancer cells in ovari- an tissue before cryopreservation.

Although many cancer types do not always metastasise to the ovary, some cancers, such as leukaemia, may confer a high risk due to their systemic nature. Neuroblastoma, breast cancer, and also cancers of gastrointestinal origin may also carry a risk for micrometastasis to the ovary. Histological evaluation of multiple ovarian tissue samples should be performed to minimise this risk before cryopreservation. Moreover, in leukaemia and lymphoma patients, cancer cells should be screened for tumour markers (i.e. b2 microglobulin, $\mathrm{LDH}$, uric acid), and immunohistochemical or other molecular analysis methods should be performed. In patients who undergo oophorectomy due to a genetic predisposition towards ovarian cancer due to $\mathrm{mu}$ tations of tumour suppressor genes such as BRCA-1 and BRCA-2, implantation of the same tissue confers greater risk of potential future malignancy. This procedure is also not recommended in cases of ovarian cancer, because malignant cells might spread throughout the body again.

\section{Methods For Fertility Preservation}

The Ethics Committee of the American Society for Reproductive Medicine (ASRM) has approved sperm cryopreservation in men and assisted reproductive techniques (ART) in women to achieve embryo cryopreservation.5 Most fertility preservation strategies are still considered to be at an experimental stage, and do not guarantee full recovery of fertility. Current strategies and future treatment options are shown in Table $1 .^{3}$

\section{Cryopreservation and Transplantation of Ovarian Tissue}

In women, cryopreservation of whole/cortical ovarian tissue before receiving chemo/radiotherapy, and transplantation of thawed ovarian tissue after full recovery is an effective method for preserving fertility. This method has advantages for the preservation of both endocrine function (i.e. regaining ovarian hormonal secretions), and reproductive function (i.e. preserving the oocyte/follicular 


\begin{tabular}{|l|}
\hline Table 1. Fertility preservation methods \\
\hline 1. Cryopreservation of embryos \\
\hline 2. Cryopreservation of ovarian tissue of whole ovary for future transplantation \\
\hline 3. Cryopreservation of oocytes for future fertilisation, embryo retrieval, and transfer \\
\hline $\begin{array}{l}\text { 4. Storage of frozen ovarian tissue or primordial follicles isolated from ovarian tissue for in vitro growth and } \\
\text { maturation }\end{array}$ \\
\hline 5. Ovarian transposition before radiotherapy \\
\hline 6. Hormonal prophylaxis with gonadotropin-releasing hormone (GnRH) analogues \\
\hline 7. Pharmacologic prophylaxis with antiapoptotic (sphingosine-1-phosphate) agents \\
\hline 8. Uterine transplantation in patients with uterine agenesis or non-functional uterus \\
\hline
\end{tabular}

reservoir).

Cryopreservation of ovarian tissue is a particularly promising method in the preservation of gonadal function during the prepubertal period, in that these patients do not require ovarian stimulation. A partner is not required for the procedure, and it can be applied without any delay. At the same time, the cryopreserved ovarian tissue provides a source of follicles for in vitro maturation (IVM), if necessary. Immature oocytes are smaller than mature ones, and are also more resistant to freezing and thawing procedures. Furthermore, during autotransplantation there is no need for immunosuppressive treatment.

Alkylating agents, such as chlorambucil, cyclophosphamide, ifosfamide, mechlorethamine, melphalan, and ionising radiation in particular frequently lead to ovarian failure. Among paediatric cancers, in particular Hodgkin's lymphoma, Wilms tumor, B-cell nonHodgkin lymphoma (B-NHL), which are treated with RT or alkylating agents, ovarian cryopreservation can be regarded as a suitable alternative treatment. ${ }^{6,7}$

After accumulating sufficient experience in experimental ovarian autograft studies in animals, the same technique is now being applied in humans. ${ }^{8}$ However, due to technical and ethical issues [Fig. 1], this treatment is still considered experimental in humans, although there is a wide range of indications for ovarian tissue cryopreservation, as shown in Table 2.

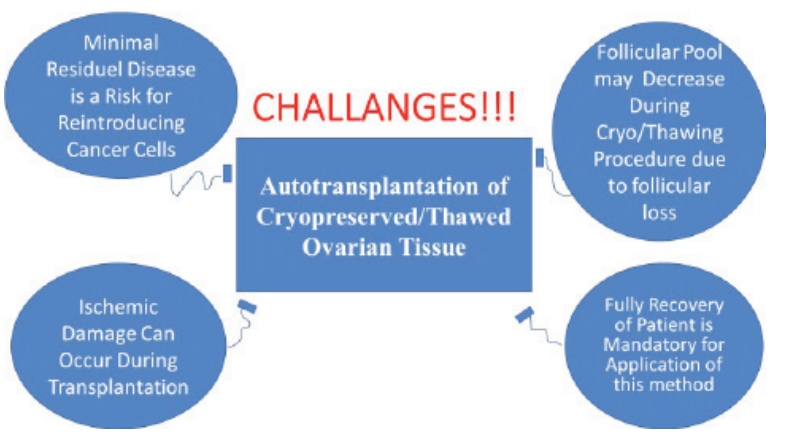

Figure 1. Challenges for cryopreservation and transplantation of ovarian tissue

\section{Ovarian Follicular Pool and Cryopreservation Proce- dures (Slow Freezing versus Vitrification)}

First of all, a possible decrease in the ovarian follicular pool as a result of cryopreservation and thawing procedures is the first challenge of autograft applications. In the last decades, researchers are intensively trying to determine the best method of human ovarian cryopreservation by comparing the two methods, 'slow freezing' and 'vitrification'. Currently, the most common methods for the evaluation of cryopreserved ovarian tissue in terms of its functionality are as follows; investigation of histomorphological changes, apoptotic gene expressions and immunohistochemical localization of protein markers for proliferation and apoptosis. However, these end-points do not reflect true ovarian function. The gold standard for the success of 


\begin{tabular}{|c|c|}
\hline \multicolumn{2}{|c|}{ Table 2. Indications for ovarian tissue cryopreservation } \\
\hline \multirow{7}{*}{ Cancer in children } & Hodgkin's and non-Hodgkin's lymphoma \\
\hline & Leukaemia \\
\hline & Ewing's sarcoma \\
\hline & Wilms' tumour \\
\hline & Neuroblastoma \\
\hline & Pelvic osteosarcoma \\
\hline & Genital rhabdomyosarcoma \\
\hline \multirow{4}{*}{ Breast cancer } & Infiltrative ductal histological subtype \\
\hline & Infiltrative lobular \\
\hline & Stage I-III \\
\hline & Stage IV \\
\hline \multirow{2}{*}{ Cervical cancer } & Squamous cell carcinoma \\
\hline & Adeno/adenosquamous carcinoma \\
\hline \multirow{12}{*}{ Autoimmune and haematological diseases } & Systemic lupus erythematosus \\
\hline & Behçet's disease \\
\hline & Steroid resistant glomerulonephritis \\
\hline & Inflammatory bowel disease \\
\hline & Pemphigus vulgaris \\
\hline & Rheumatoid arthritis \\
\hline & Progressive systemic sclerosis \\
\hline & Juvenile idiopathic arthritis \\
\hline & Multiple sclerosis \\
\hline & Autoimmune thrombocytopenia \\
\hline & Aplastic anaemia \\
\hline & Sickle cell disease \\
\hline \multirow{2}{*}{ Benign ovarian disease } & Endometriosis \\
\hline & Benign ovarian lesions requiring repeated surgeries \\
\hline \multirow{6}{*}{ Patients receiving pelvic radiation } & Ewing's sarcoma \\
\hline & Osteosarcoma \\
\hline & Tumours of the spinal cord \\
\hline & Retroperitoneal sarcoma \\
\hline & Rectal cancer \\
\hline & Benign bone tumours \\
\hline \multirow{2}{*}{ Prophylactic oophorectomy } & BRCA-I-positive patients \\
\hline & BRCA-II-positive patients \\
\hline \multirow{2}{*}{ Hematopoietic stem cell transplantation } & Malignant diseases \\
\hline & Genetic, haematological, and autoimmune disorders \\
\hline
\end{tabular}


a fertility preservation method is live birth, which can take several years to achieve. ${ }^{9,10}$

The results of previous studies comparing the two methods are controversial due to various protocols employed for cryopreservation. But apparently, slow freezing and vitrification of human ovarian tissue result in similar morphological integrity, estradiol release, follicular proliferation and apoptosis rate, in vitro. ${ }^{11}$

Zhou et al. in 2016 showed that vitrification and slow freezing techniques result in equivalent numbers of intact primordial follicles. ${ }^{12}$ Herraiz et al. demonstrated that vitrification of bovine ovary using ethylene glycol (EG), dimethyl sulfoxide (DMSO), sucrose, and synthetic serum substitute offers higher follicular density, proliferation, and viability, lower cell death and, could preserve a larger population of quiescent follicles than slow freezing or other vitrification protocols. ${ }^{13}$

Moreover, Luyckx et al. have reported that transplantation of human cryopreserved prepubertal ovarian tissue to mice demonstrated that a very high number of follicles survive after transplantation and a large pool of primordial follicles remains dormant. In addition, growing follicles were observed, proving the responsiveness of prepubertal ovarian tissue to gonadotropins. ${ }^{14}$

Actually, the two methods have their own advantages and disadvantages. Slow freezing, which is known as equilibrium freezing, requires low concentration of cryoprotectants which is less toxic, but may be insufficient for avoiding ice crystal formation within the cells. It is more time consuming and requires an expensive programmable freezing machine, Vitrification is now regarded as a potential alternative to the conventional slow freezing method. This method is a non-equilibrium ultra-rapid method of cryopreservation with extremely fast rates of cooling where by embryo/ovarian tissue is transitioned from $37^{\circ} \mathrm{C}$ to $-196^{\circ} \mathrm{C}$ (in liquid nitrogen) in $<1$ minute. It has the advantage of preventing ice crystal formation by a short exposure to high concentrations of cryoprotectants with low water content and eliminating the use of expensive equipments. The main drawback is exposure of the tissue to a high concentration of cryoprotectants which may have a detrimental effect. This can be minimized by allowing a very short exposure i.e. 30-40 seconds, combining several cryoprotectants and using a less toxic cryoprotectant. Some of the commonly used cryoprotectants are DMSO, glycerol, ethylene glycol, propanediol, and sugars. ${ }^{15}$

\section{Loss of Follicle due to Post-transplantation Ischemia}

The second main challenge for autograft applications is the post-transplantation ischemia which reduces the lifespan of a graft, and causes massive loss of follicles in the early stages after transplantation. In fact, ischemia is much more detrimental to ovarian tissue than freezing/thawing injuries. $^{16}$

Although ovarian tissue is well endowed with angiogenic factors, the process of angiogenesis requires more than $48 \mathrm{~h}$ to revascularise a cortical slice; thus, ovarian grafts are subject to hypoxia, which leads to follicular loss. The survival rate of primordial follicles after transplantation ranges from $5 \%$ to $50 \%$. Though the ovary becomes revascularised within $48 \mathrm{~h}$ after transplantation in rodents, revascularisation may occur more slowly in human ovarian grafts, as they are inherently more fibrous, with a reduced follicle density. ${ }^{17}$ In this context, one of the most important questions to be resolved for successful ovarian transplantation is how to minimise ischemic injuries before and during the establishment of angiogenesis in ovarian grafts. Because ovarian reserve correlates with the number of follicles in the ovary, the significant follicular loss caused by ischemia after transplantation can directly affect ovarian reserve and subsequent longevity of ovarian function. Thus, the degree of success in minimising follicular loss will determine the efficacy of ovarian tissue transplantation. In recent years, many experiments have aimed to 
reduce ischemic damage in transplanted ovaries. For instance, Nugent et al. reported that antioxidant treatment using vitamin $\mathrm{E}$ improved the survival of follicles in ovarian grafts by reducing ischemic injury. ${ }^{18}$

In this context, we have an ongoing research project investigating whether catestatin, a novel proangiogenic agent reduces ischemic tissue damage and protects cryopreserved/ thawed ovarian tissue grafts in rats against apoptosis and follicular loss. Vitrification was used as the cryopreservation method, and whole ovarian autotransplantation to the back muscle was performed. Our preliminary data shows that both freeze/thaw and transplantation cause a significant loss of follicular pool and that much more primordial and primary follicles degenerate from ischemia and reperfusion than from freezing/thawing injury (Figure 2; A-D) (Project number: TSA-2016-1830, Akdeniz University BAP Research Project Commision, Project title: The investigation of the effects of cryopreservation and autotransplantation of rat ovarian tissue on the expression of angiogenic factors and mast cells and the effect of catestatin application on these values.)
Moreover, recent investigations also suggest that microvascular transplantation of cryopreserved whole ovaries may allow immediate revascularisation, ensuring better fertility preservation.

\section{Reimplantation of the Primary Tumour}

One of the most important concerns with ovarian tissue cryopreservation is the possibility of re-seeding a tumour. Theoretically, ovarian tissue may carry micro-metastases that could "re-infect" a patient who had been previously cured of her cancer.

Ovarian transplantation might be particularly risky in blood-born malignancies, such as leukaemia, in which cancer cells are already in the blood, and therefore presumably within the cryopreserved ovarian tissue. Shaw et al. showed that fresh and cryopreserved ovarian tissue samples taken from donors with lymphoma transmitted the cancer into previously healthy graft recipients. ${ }^{19}$

Ideally, ovarian tissue cryopreservation should be performed in patients with a low risk of cancer metastasis to ovaries. Most of the malignancies encountered in the re-

\section{Fig 2. (A-D) Histologic illustrations of ovarian tissue from wistar rats (4-6 weeks' of age) (H\&E)}

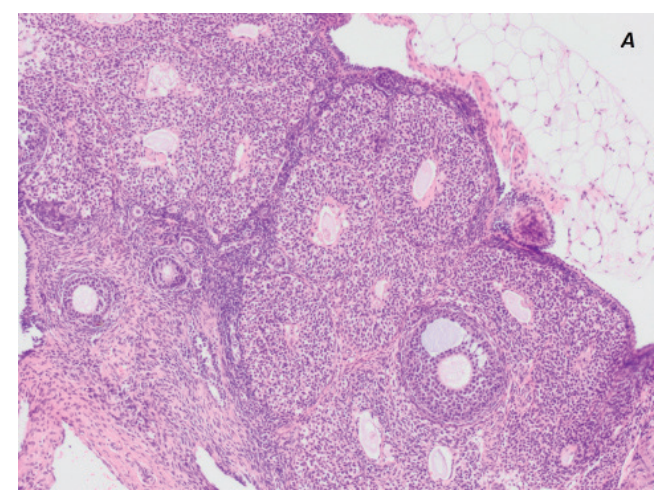

(A) Control group. Normal ovarian histological appearance with a large pool of primordial follicles, besides intact primary and secondary follicles are seen (x100).

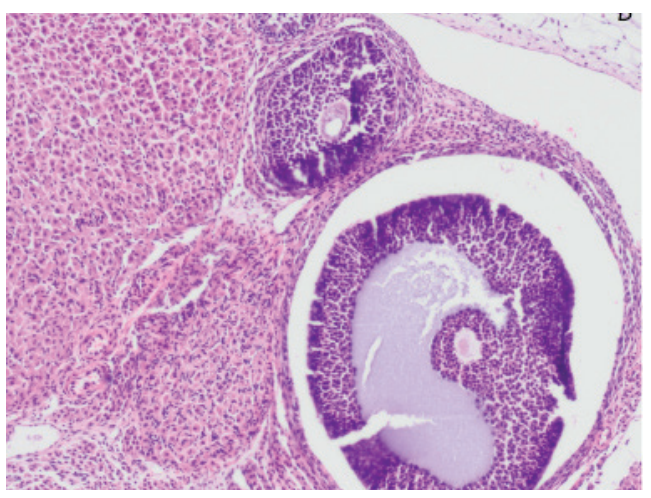

(B) Frozen-thawed ovarian tissue. Diminished pool of primordial follicles, besides degenerated primary and secondary follicles are observed (x100). 


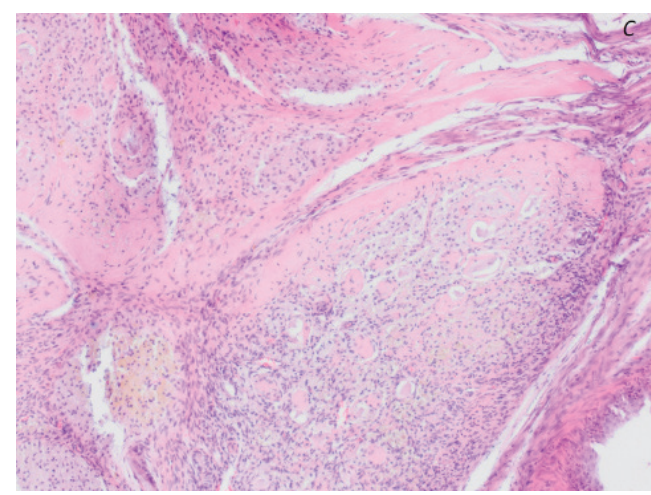

(C) Fresh ovarian tissue after grafting. A few intact primordial and growing follicles besides many atrophic follicles were observed (x100).

productive years do not metastasise to the ovaries. The risk of ovarian metastasis according to cancer type is shown in Table 3.

As summarised by Sönmezer and Oktay, the cancers with high risk of ovarian involvement are leukaemia, Burkitt's lymphoma, neuroblastoma, and genital rhabdomyosarcoma. ${ }^{20-23}$ Patients with high-risk cancers should not be given the option of ovarian autotransplantation, or ovarian tissue harvest should be performed after the first round of CT to ablate any neoplastic cells residing within the ovary. ${ }^{24}$ However, this method of application carries a risk of diminishing the ovarian reserve with each cycle of CT.

To eliminate reimplantation of the primary tumour, alternative techniques, such as IVM of primordial follicles or ovarian tissue xenografting, can be applied in patients with a high risk of minimal residual disease. ${ }^{25,26}$ Regardless of the risk of the cancer involved, a histological assessment for micrometastases must be made on portions of the removed ovarian tissue before cryopreservation to avoid transplanting tissue that contains cancer. ${ }^{27}$

Currently, there is no guarantee that ovarian tissue transplantation in a woman in whom the tissue was collected at the time of active cancer disease can be regarded as $100 \%$

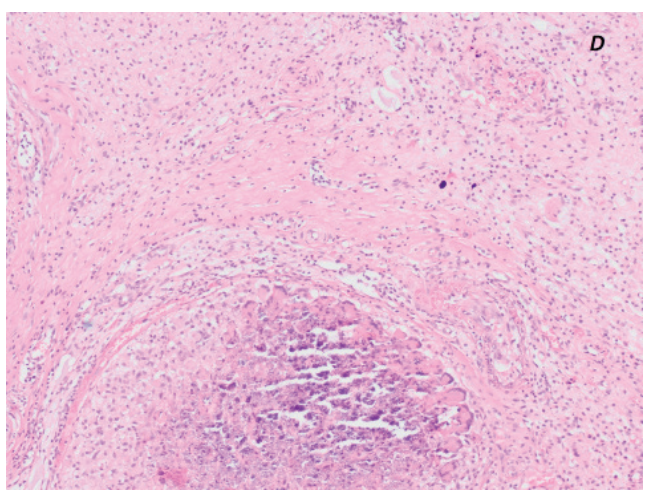

(D) Frozen-thawed and grafted ovarian tissue. Many atrophic follicles and degenerated primary follicles, besides a few intact primordial follicles are seen. Dystrophic calsification and necrosis can also be noticed (x100).

disease-free and safe. Confidential and simple methods to detect whether the ovarian tissue to be transplanted harbours cancer cells are urgently needed and further research is required.

The most frequently used in vitro methods to detect malignant cell contamination in ovarian tissue that are available for individual patients include; histology, immunohistochemistry, and detecting molecular markers using reverse transcription/quantitative polymerase chain reaction (RT/ QPCR). Although each of these methods has its individual strengths and weaknesses, none of them is perfectly suited to detect malignant cells. Histology has been validated for many years, and the use of immunohistochemistry is also prevalent. However, both methods are relatively insensitive. Immunohistochemistry is also prone to both false-negative and false-positive results. ${ }^{28}$ Molecular markers are highly sensitive, but detecting genetic material from nonviable malignant cells that do not survive may also occur. ${ }^{29}$ Furthermore, most tumours do not display any detectable molecular markers.

Importantly, patients should be fully aware that pieces of tissue used for grafting cannot be fully checked for contamination with residual disease, and that safety cannot be $100 \%$ guaranteed. On the other hand, if residual ma- 


\begin{tabular}{|l|l|l|l|}
\hline \multicolumn{2}{|c|}{ Lable 3. The risk of ovarian metastasis. } & \multicolumn{1}{c|}{ Moderate risk } & \multicolumn{1}{c|}{ High risk } \\
\hline $\begin{array}{l}\text { Squamous cell carcinoma of the } \\
\text { cervix }\end{array}$ & Breast cancer & Stage IV & Leukemia \\
\hline Ewing's sarcoma & W & $\begin{array}{l}\text { Infiltrative } \\
\text { lobular }\end{array}$ & Burkitt's lymphoma \\
\hline Breast cancer & Stage I-III & $\begin{array}{l}\text { Colon cancer (including tumors of } \\
\text { rectum and appendix) }\end{array}$ & Neuroblastoma \\
\hline Infiltrative ductal & $\begin{array}{l}\text { Adeno/adenosquamous carcinoma of } \\
\text { the cervix }\end{array}$ & Genital rhabdomyosarcoma \\
\hline Wilms' tumor & $\begin{array}{l}\text { Upper gastrointestinal system malig- } \\
\text { nancies }\end{array}$ & \\
\hline Non-Hodgkin's lymphoma & & \\
\hline Hodgkin's lymphoma & & \\
\hline Osteogenic sarcoma & & \\
\hline Non-genital rhabdomyosarcoma & & \\
\hline
\end{tabular}

lignant cells have been localised to ovarian tissue, ovarian tissue transplantation should obviously not be performed. Generally, a cancer patient is considered disease-free after treatment, which may imply that malignant cells are not completely absent from the patient but only present at subclinical levels. However, the actual number of malignant cells is unknown. The question is therefore: how many malignant cells are necessary to cause a relapse? Again, the answer is unknown in humans for most cancers, but studies in rats have shown that just a few malignant leukemic cells are sufficient to cause a relapse ${ }^{30,31}$

The number of malignant cells introduced back into the patient is dependent on the number of ovarian tissues transplanted. The number of autotransplanted tissues may vary from three fragments to more than ten, and this will clearly impact the number of malignant cells potentially transplanted. However, the number of cells needed to cause relapse in connection with ovarian tissue transplantation in humans is completely unknown.
Finally, the contributions of cancer stem cells (CSCs) to cancer progression should also be emphasised here. These cells, which were first identified in leukaemia, are a population of stem-like cells. They have been reported to possess the abilities of self-renewal, invasion, metastasis, and engraftment of distant tissues. The CSC hypothesis attempts to explain tumour cell heterogeneity based on the existence of stem cell-like cells within solid tumours. In fact, the elimination of CSCs is challenging for most human cancer types due to their heightened genetic instability and increased drug resistance. ${ }^{32}$ In this context, the detection of CSCs in an ovarian graft is of great importance, and requires further investigation.

\section{Orthotopic and/or Heterotopic Transplantation of Ovarian Tissue}

The most frequently applied method for cryopreservation and transplantation of ovarian tissue is reimplantation of small frozen cortical sections of ovary retrieved from the patient before initiation of cancer therapy. After treatment is terminated and remission achieved, those frozen tissue 
specimens are thawed, and subjected to orthotopic and/or heterotopic autotransplantation. ${ }^{3}$ In orthotopic transplantation of ovarian tissue, after tissue sections are thawed, they are placed in their proper anatomical place in the ipsilateral or contralateral ovary or immediately beneath this area. Thus, this procedure enables natural fertilisation, but on the other hand, it requires abdominal surgery and general anaesthesia. A laparoscopic approach, which is less invasive, is an alternative to abdominal surgery.

Ovarian stimulation in female patients after orthotopic autotransplantation of frozen/thawed ovarian cortical tissue has successfully achieved ovulation. ${ }^{25}$ Donnez et al. published the first case of successful pregnancy and live birth in a patient with a previous history of CT and RT for lymphoma treatment who had undergone autotransplantation with frozen/thawed ovarian tissue. ${ }^{6}$ Meirow et al. also performed in vitro fertilisation and reported the first case of live birth following orthotopic autotransplantation of frozen ovarian tissue in a patient who had developed premature ovarian failure after CT. ${ }^{7}$

In heterotopic autotransplantation of ovarian tissue, the graft is implanted in subcutaneous tissue of the forearm or abdominal wall. The advantage of heterotopic autotransplantation is that the surgery is less invasive. Furthermore, it does not require general anaesthesia and the surgical wound heals rapidly. However, it is difficult to monitor follicular maturation, and there is no chance of spontaneous pregnancy. Restoration of ovarian function has been reported an average of 2 years following implantation of heterotopic autografts to subcutaneous tissue covering the brachioradial fascia of the forearm. Researchers have even percutaneously aspirated oocytes in a patient. 9 Since the first birth in 2004, more than 20 healthy children have been born worldwide to women who underwent autotransplantation of frozen/thawed ovarian cortex. ${ }^{33-37}$

\section{Conclusions}

As techniques improve and clinical indications expand, ovarian tissue cryopreservation offers the ability to protect and extend reproductive capacity. Other clinical options for women and girls who face a high likelihood of diminished or absent ovarian reserve resulting from obligatory disease treatments may be limited or non-existent. However, before cryopreservation of ovarian tissue becomes as a practice, well-standardised and improved methods are required for all stages of the procedure, from the freeze/ thaw process to transplantation. The development of strict evaluation criteria regarding the risk of reintroducing malignant cells via transplantation of ovarian grafts is also mandatory. The emerging role of CSCs in ovarian grafts should also be investigated further in different types of cancer.

Finally, when seeking patient consent for ovarian tissue cryopreservation, a thorough discussion must ensue regarding the fate of the tissue and the inherent procedural risks to the health of the patient. Moreover, clinicians must consider that many patients might not fully recover from their illness, and may experience a chronic course of the disease. Therefore, every patient should be carefully assessed individually. 
Sakarya Med J 2019;9(1):1-10

AYDIN et al. Autotransplantation of Cryopreserved/Thawed Ovarian Tissue

\section{References}

1. American Cancer Society. Special section: obesity. Cancer Facts and Figures 2001. 1st ed. Atlanta GA: National Media Office; 2001; 20-7.

2. Blatt J. Pregnancy outcomes in long-term survivors of childhood cancer. Med Pediatr Oncol 1999; 33:29-33.

3. Bedaiwy MA, Shahin AY, Falcone T. Reproductive organ transplantation: advances and controversies. Fertil Steril 2008; 90:2031-55.

4. Howell SJ, Sharlet SM. Fertility preservation and management of gonadal failure associated with lymphoma therapy. Curr Oncol Rep 2002; 4:443-52.

5. Ethics Committee of the American Society for Reproductive Medicine. Fertility preservation and reproduction in cancer patients. Fertil Steril 2005; 83:1622-8.

6. Donnez J, Dolmans MM, Demylle D, et al. Livebirth after orthotopic transplantation of cryopreserved ovarian tissue. Lancet 2004; 364:1405-10.

7. Meirow D, Levron J, Eldar-Geva T, et al. Pregnancy after transplantation of cryopreserved ovarian tissue in a patient with ovarian failure after chemotherapy. N Engl J Med 2005; 353:318-21.

8. Torrents E, Boiso I, Barri PN, Veiga A et al.. Applications of ovarian tissue transplantation in experimental biology and medicine. Hum Reprod Update. 2003;9:471-81.

9. Ting A. Y., RR Yeoman, Campos JR, Lawson M.S., Mullen S.F., Fahy G.M. et al. Morphological and functional preservation of pre-antral follicles after vitrification of macaque ovarian tissue in a closed system. Human Reproduction, 2013, 28.5: 1267-1279.

10. 10. Dalman A. NSDG Farahani, Totonchi M., Pirjani R., Ebrahimi B., Valojerdi M.R., et al. Slow freezing versus vitrification technique for human ovarian tissue cryopreservation: An evaluation of histological changes, WNT signaling pathway and apoptotic genes expression. Cryobiology, 2017, 79: 29-36.

11. Klocke S., Bündgen N., Köster F., Eichenlaub-Ritter U., Griesinger G. Slow-freezing versus vitrification for human ovarian tissue cryopreservation. Archives of gynecology and obstetrics, 2015, 291.2: 419-426.

12. Zhou XH, Zhang D, Shi J, Wu YJ. Comparison of vitrification and conventional slow freezing for cryopreservation of ovarian tissue with respect to the number of intact primordial follicles: A meta-analysis. Medicine (Baltimore). 2016 Sep;95(39):e4095.

13. S. Herraiz, E. Novella-Maestre, B. Rodríguez, C.Díaz, M. Sánchez Serrano, V. Mirabet, et al. Improving ovarian tissue cryopreservation for oncologic patients: slow freezing versus vitrification, effect of different procedures and devices. Fertil. Steril., 101 (2014), pp. 775-784.

14. Luyckx V, Scalercio S, Jadoul P, Amorim CA, Soares M, Donnez J, et al. Evaluation of cryopreserved ovarian tissue from prepubertal patients after long-term xenografting and exogenous stimulation. Fertil Steril. 2013;100(5):1350-7.

15. Son WY., Tan SL. Comparison between slow freezing and vitrification for human embryos. Expert review of medical devices, 2009, 6.1:1-7.

16. Aubard, Y., Piver, P., Cogni, Y., Fermeaux, V., Poulin, N., Driancourt, M.A. Orthotopic and heterotopic autografts of frozen-thawed ovarian cortex in sheep. Hum Reprod. 1999; 14: $2149-2154$.

17. Dissen, G. A., Lara H.E., Fahrenbach W. H. ,Costa M.E., Ojeda S.R.. "Immature rat ovaries become revascularized rapidly after autotransplantation and show a gonadotropin-dependent increase in angiogenic factor gene expression." Endocrinology 134.3 (1994): 1146-1154.

18. Nugent $D$., et al. Protective effect of vitamin $E$ on ischaemia-reperfusion injury in ovarian grafts. Journal of reproduction and fertility, 1998, 114.2: 341-346.
19. Shaw JM, Bowles J, Koopman P, et al. Fresh and cryopreserved ovarian tissue from donors with lymphoma, transmit the cancer to graft recipients. Hum Reprod 1996; 11:1668-73.

20. Sonmezer M, Oktay K. Fertility preservation in female patients. Hum Reprod Update 2004, 10:251-66.

21. Chu JY, Craddock TV, Danis RK, et al. Ovarian tumor as manifestation of relapse in acute lymphoblastic leukemia. Cancer 1981; 48:377-9.

22. Yada-Hashimoto N, Yamamoto T, Kamiura S, et al. Metastatic ovarian tumors: a review of 64 cases. Gynecol Oncol 2003; 89:314-7.

23. McCarville MB, HillDA, Miller BE, et al. Secondary ovarian neoplasms in children: imaging features with histopathologic correlation. Pediatr Radiol 2001; 31:358-64.

24. Sonmezer M, Shamonki MI, Oktay K. Ovarian tissue cryopreservation: benefits and risks. Cell Tissue Res 2005; 322:125-32.

25. Oktay K, Newton H, Mullan J, et al. Development of human primordial follicles to antral stages in SCID/hpg mice stimulated with follicle stimulating hormone. Hum Reprod 1998; 13:1133-8.

26. Oktay K, Newton H, Gosden RG. Transplantation of cryopreserved human ovarian tissue results in follicle growth initiation in SCID mice. Fertil Steril 2000; 73:599-603.

27. Oktay KH, Yih M. Preliminary experience with orthotopic and heterotopic transplantation of ovarian cortical strips. Semin Reprod Med 2002; 20:63-74

28. Rosendahl M, Tolstrup Andersen $M$, et al. Evidence of residual disease in cryopreserved ovarian cortex from female patients with leukaemia. Fertil Steril. 2010; 94:2186-90.

29. Bastings L, Beerendonk CC, Westphal JR, et al. Autotransplantation of cryopreserved ovarian tissue in cancer survivors and the risk of reintroducing malignancy: a systematic review. Hum Reprod Update. 2013; 19:483-506.

30. Hou M, Andersson M, Eksborg S, et al. Xenotransplantation of testicular tissue into nude mice can be used for detecting leukemic cell contamination. Hum Reprod. 2007; 22:1899906.

31. Jahnukainen $K$, Hou M, Petersen C, et al. Intratesticular transplantation of testicular cells from leukemic rats causes transmission of leukemia. Cancer Res. 2001; 61:706-10.

32. Lee D, Suh DS, Lee SC, Tigyi GJ, Kim JH. Role of autotaxin in cancer stem cells. Cancer Metastasis Rev. 2018. doi: 10.1007/s10555-018-9745-x.

33. Dittrich R, Lotz L, Keck G, et al. Live birth after ovarian tissue autotransplantation following overnight transportation before cryopreservation. Fertil Steril. 2012; 97:387-90.

34. Donnez J, Silber S, Andersen CY, et al. Children born after autotransplantation of cryopreserved ovarian tissue. A review of 13 live births. Ann Med. 2011; 43:437-50.

35. Revel A, Laufer N, Ben MA, et al. Micro-organ ovarian transplantation enables pregnancy: a case report. Hum Reprod. 2011; 26:1097-103.

36. Silber SJ. Ovary cryopreservation and transplantation for fertility preservation. Mol Hum Reprod. 2012; 18:59-67.

37. Andersen CY, Silber SJ, Bergholdt SH, et al. Long-term duration of function of ovarian tissue transplants: case reports. Reprod Biomed Online. 2012; 25:128-32. 